\title{
Insight into consumer experience on UK train transportation services
}

\section{Emmanuel Mogaji ${ }^{a,}$}

E.O.Mogaji@greenwich.ac.uk

\section{Ismail Erkan}

ismail.erkan@ikc.edu.tr

a Faculty of Business, University of Greenwich, London SE10 9LS, United Kingdom

${ }^{\mathbf{b}}$ Department of Business Administration, Izmir Katip Celebi University, Balatcık Mahallesi Havaalanı Sosesi, No: 33/2 Merkezi Ofisler II Kat 2, 35620 Ciğli IZMIR, Turkey

${ }^{*}$ Corresponding author

\section{Abstract}

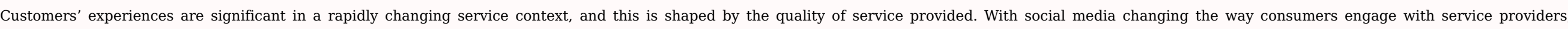

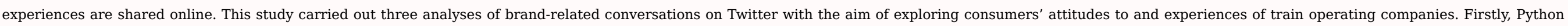

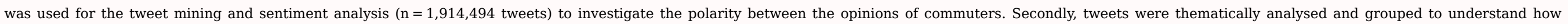

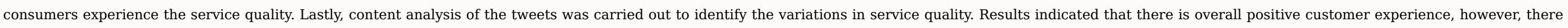

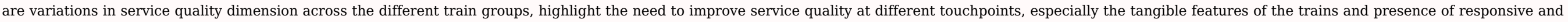

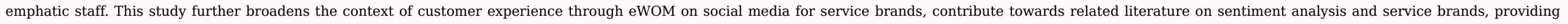
significant theoretical and practical implications for researchers and managers.

Keywords: Service experience; Sentiment analysis; Transport service; United Kingdom; Social media

\section{Introduction}

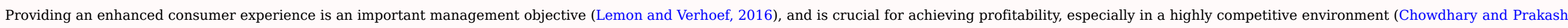

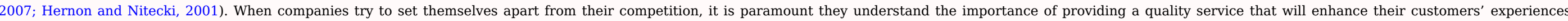

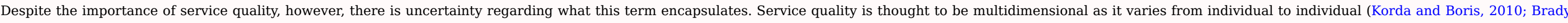

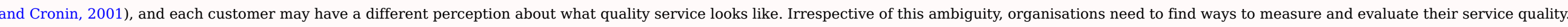

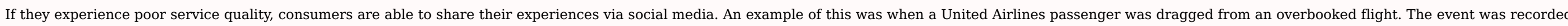

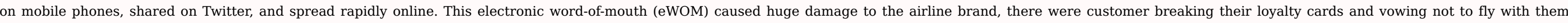

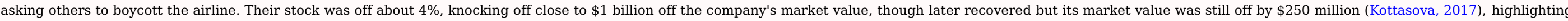

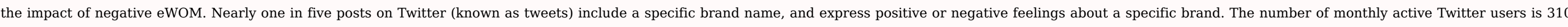
million, and the number of tweets sent per day is 500 million. This means that an average of 100 million tweets mention brands every day (Internet Live Stats, 2018).

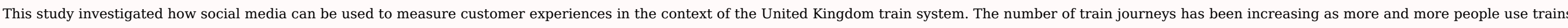

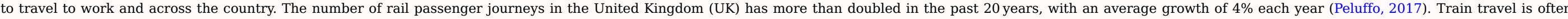






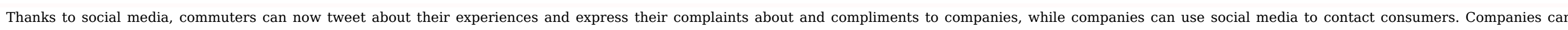

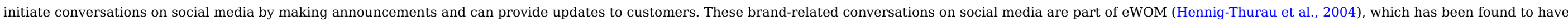



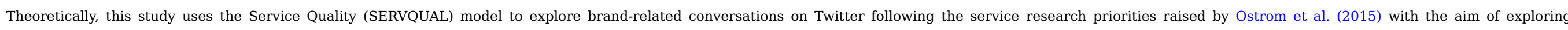



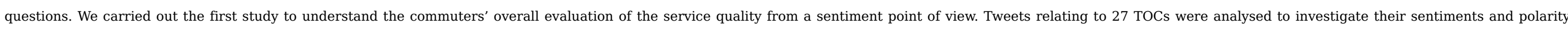

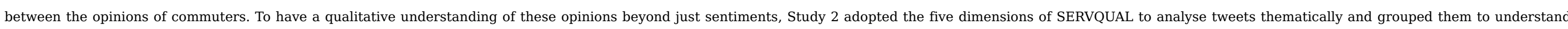

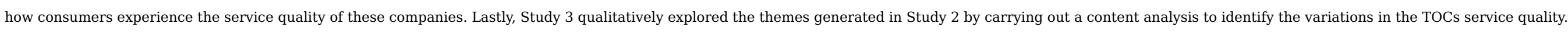

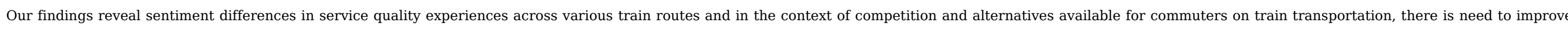

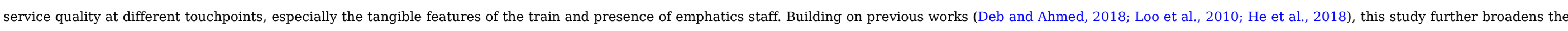

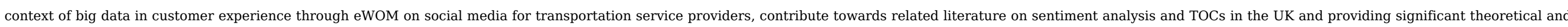
practical implications for researchers and managers.

\section{Literature review}

\subsection{The railway system in the United Kingdom}

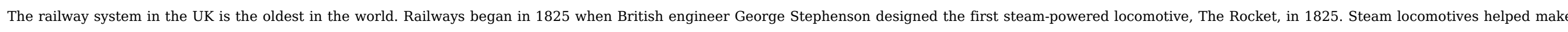

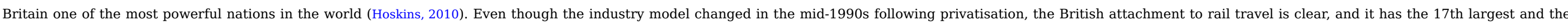
densest rail network in the world (Smith, 2016).

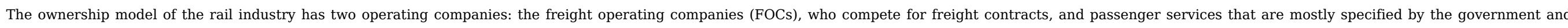

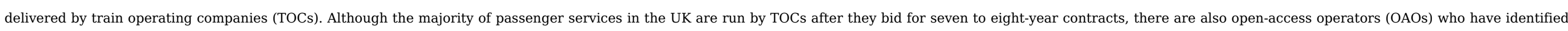

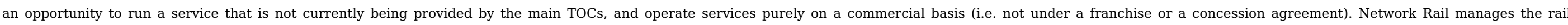
infrastructure, while the Office of Rail and Road (ORR) regulate both TOCs and OAOs in turn (Rail Delivery Group, 2016)

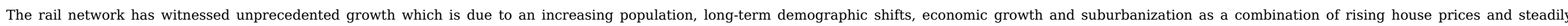

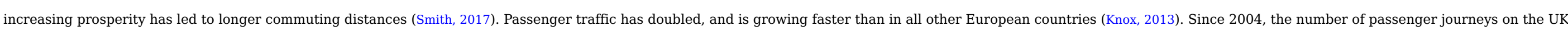

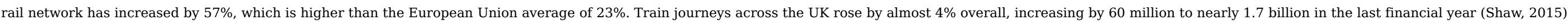
The system is undergoing one of the biggest investment programmes in its history to provide much-needed extra capacity, more services, and better journeys (Rail Delivery Group, 2016).

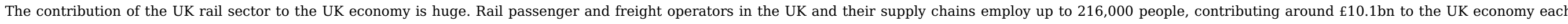

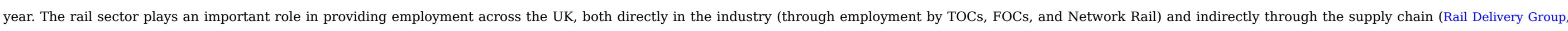

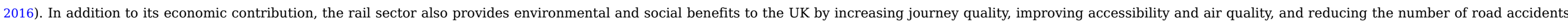
(Rail Delivery Group, 2016). The rail sector creates a more productive economy by alleviating congestion in the road network and facilitating the development of clusters of economic activity.

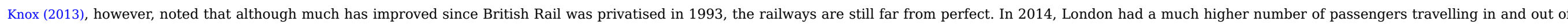



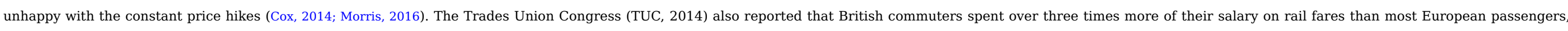

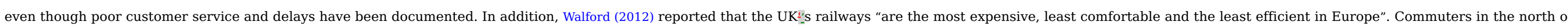

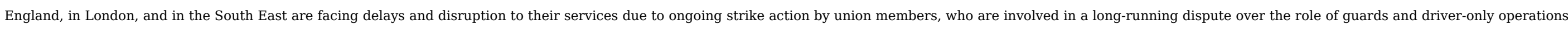
(Topham, 2018). 


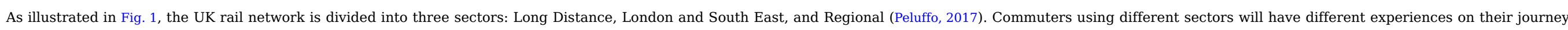
therefore, this study aimed to provide empirical evidence for understanding consumers' experiences with the TOCs in the UK.

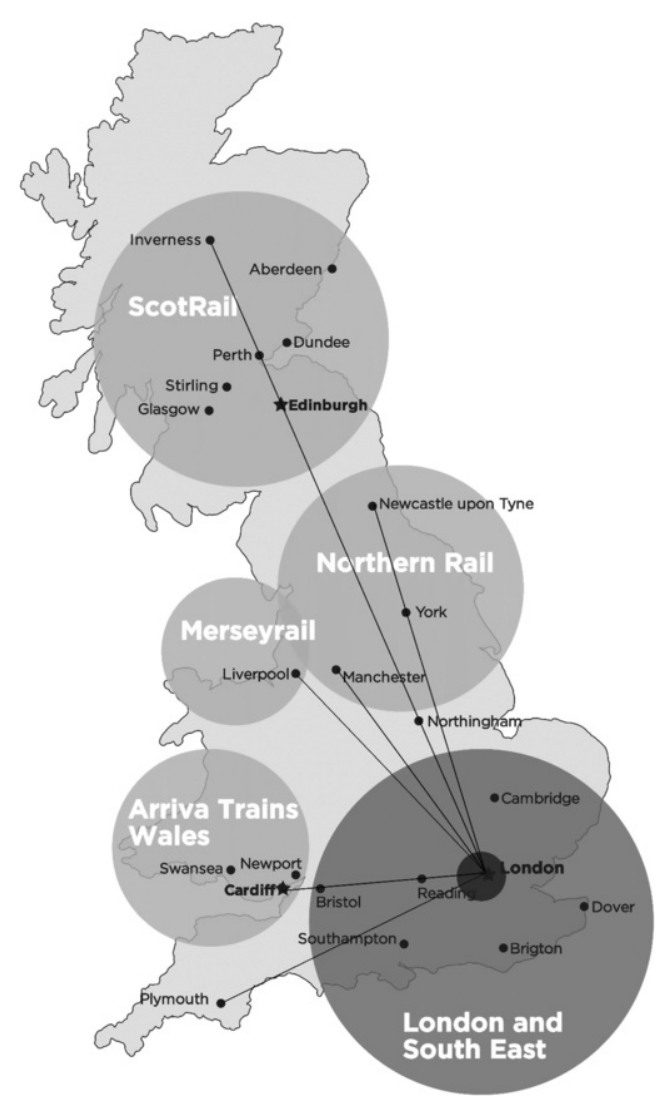

Fig. 1 The UK Rail Network.

\subsection{Train service quality}

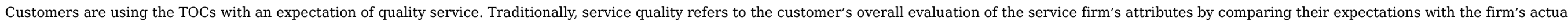

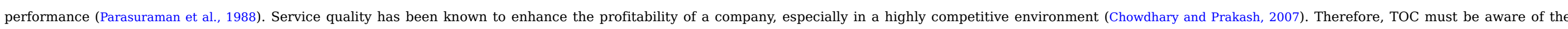
quality of the services they are offering and make efforts to improve their services.



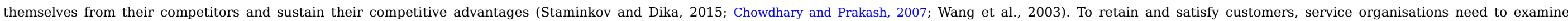
systematically the services they provide from a customer viewpoint and enrich the design of their services and the environment in which their services are delivered (Awad, 2012).

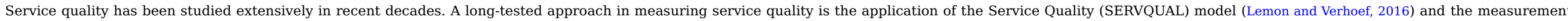

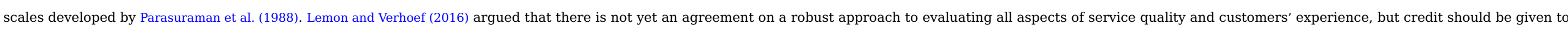

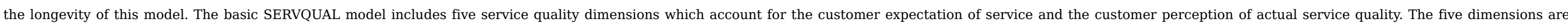
reliability, assurances, tangibles, empathy, and responsiveness, and are referred to as RATER. 


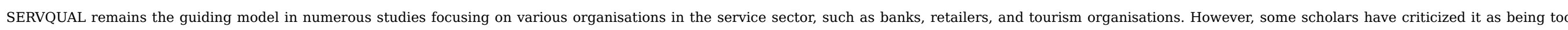

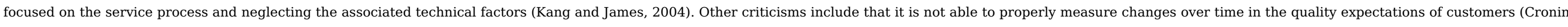
and Taylor, 1992; Hsieh and Yuan, 2011), and that it may not be able to be used in all service sectors and may need to be modified to be appropriate for those sectors (Kanning and Bergmann, 2009).

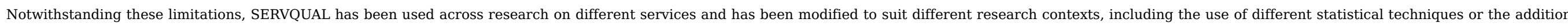

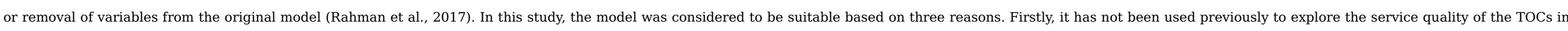

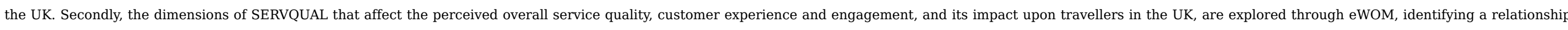
between service quality and customer engagement on social media. Finally, qualitatively operationalising these dimensions through analysis of tweets is a methodological contribution.

\subsection{Consumer experience}

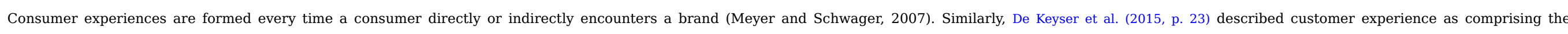

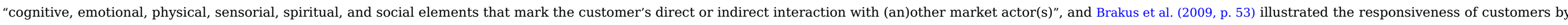
describing brand experience as "subjective, internal consumer responses (sensations, feelings, and cognition) and behavioural responses evoked by brand-related stimuli that are part of a brand's design".

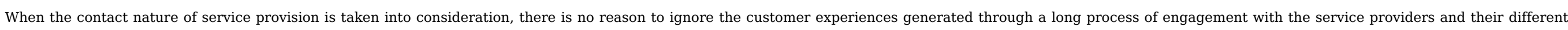
touchpoints. Homburg et al. (2017) described touchpoints as contacts between the firm and the customer at distinct points in the experience.

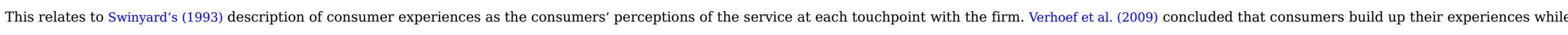

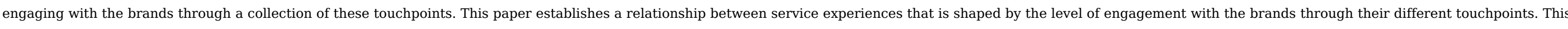

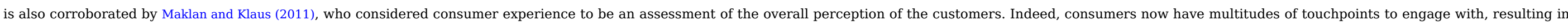
more complex customer journeys (Lemon and Verhoef, 2016).

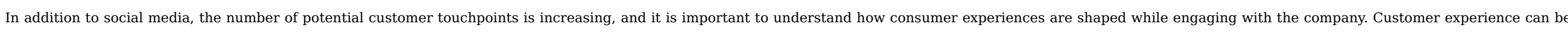
conceptualised according to three stages: pre-purchase, purchase, and post-purchase (Lemon and Verhoef, 2016). These are closely related to the brand touchpoint wheel (Davis and Dunn 2002).

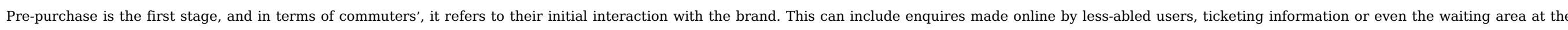

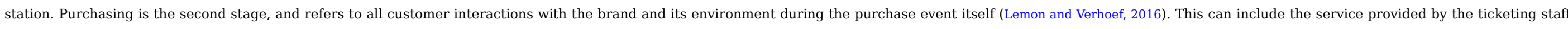

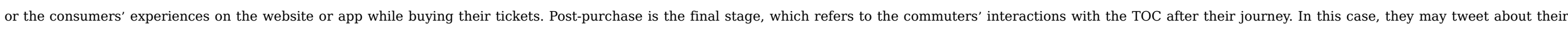
experiences and provide feedback.

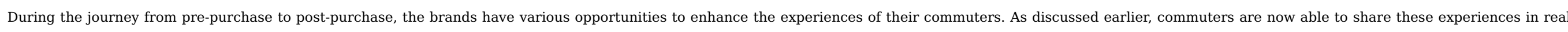

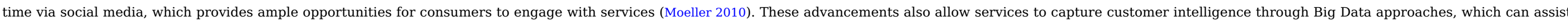
in the understanding of customer engagement behaviours (Kunz, et al. 2017).

\subsection{Consumer-brand relationships on social media}

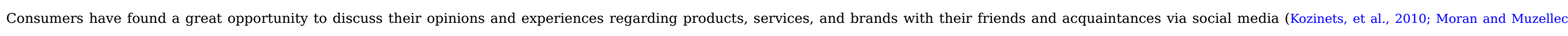

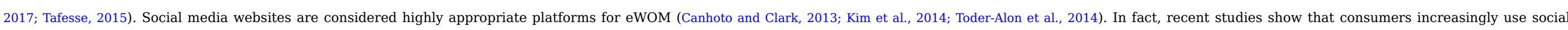
media with the aim of acquiring information about unfamiliar brands (Barreda et al., 2015; Heller Baird and Parasnis, 2011; Naylor et al., 2012).

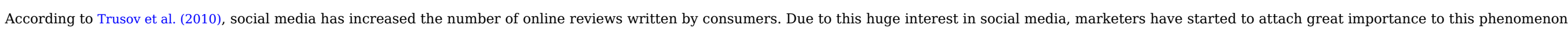

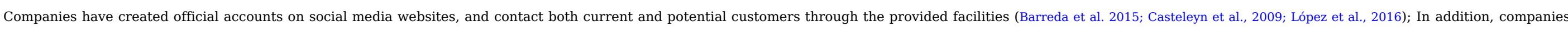

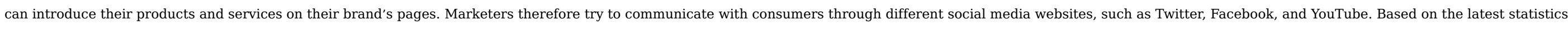

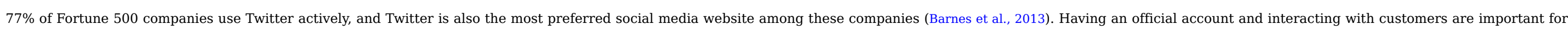




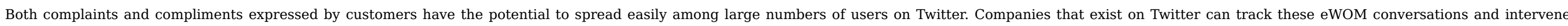

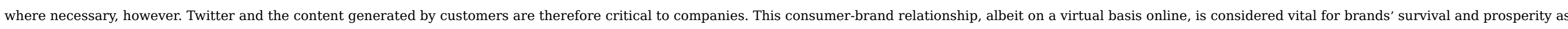
it leads to brand loyalty and contributes to increased repurchase volume and better acquisition rates (Sabrina and Shobeiri, 2016; Giovanis, 2016).

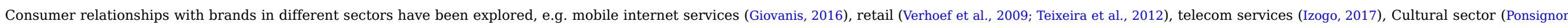

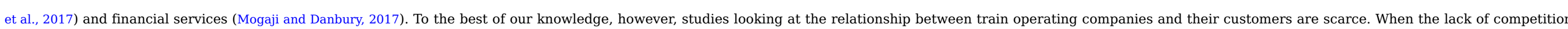

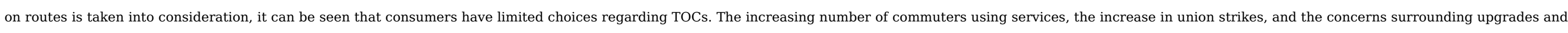
disruptions, highlight the need to understand the relationship between TOCs and their customers.

\subsection{Conceptual framework}

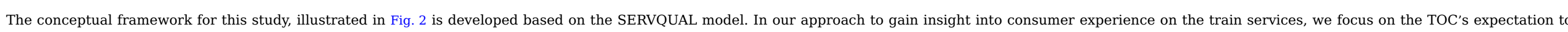


the sentiments as shared by the commuters on Twitter while the other two questions probe more in-depth to qualitatively and quantitatively provide evidence of the consumers' experience.

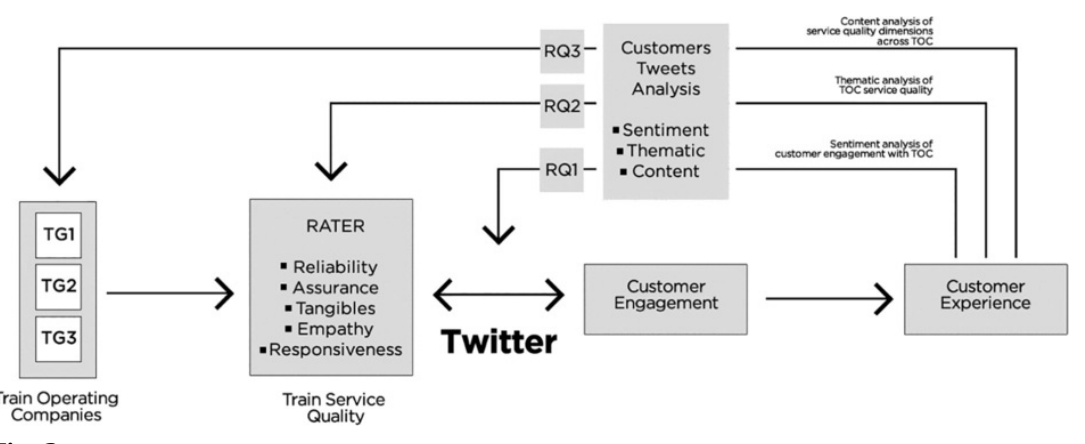

Fig. 2 The Conceptual Framework.

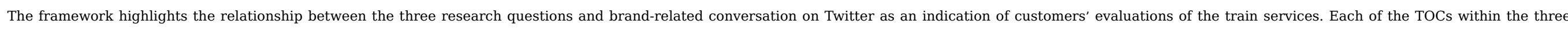

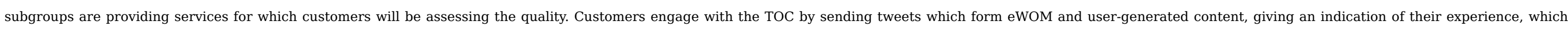
could be positive or negative.

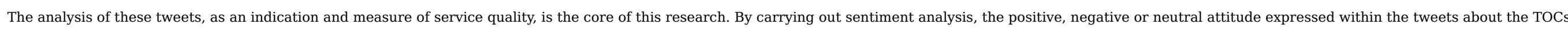

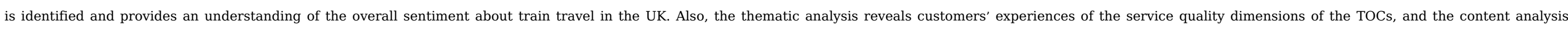
identifies any variations in service quality across the TOC groups.

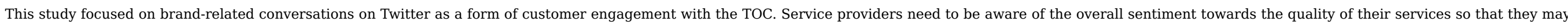
be able to identify ways to improve their services and enhance their customers' experiences and engagement, and, as a result, improve profitability.

\subsection{Research questions}

The three research questions to understand attitudes towards UK train travel are hinged on the three analyses within the conceptual framework.

Using sentiment analysis, Study 1 asked:

RQ1: As an indicators of service quality, what are the commuters' sentiments towards the UK TOCs? 
To further explore the themes generated in Study 2, content of selected tweets is analysed to answer the specific question of variation across the TOCs:

R3: How do these service quality dimensions vary across TOCs?

\subsection{Study 1 sentiment analysis}

\subsubsection{Methodology}

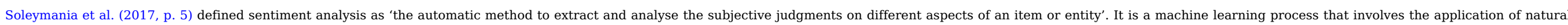
language processing to identify expressions that reflect authors' opinion-based attitudes towards entities (Li and Hovy, 2017). This process was used to analyse the sentiments in tweets by the UK TOC commuters.

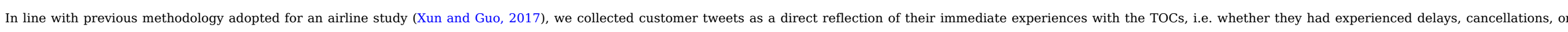

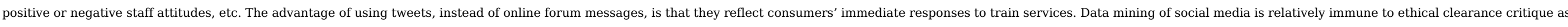

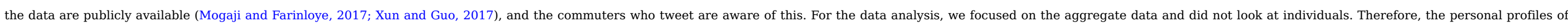
Twitter users were not collected.

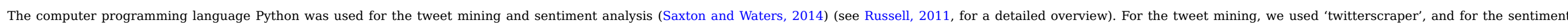

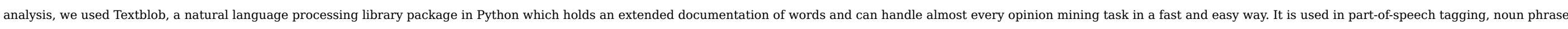

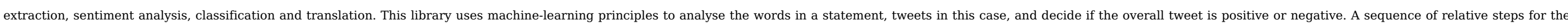
analysis is presented in the next section and illustrated in Fig. 1.

2.7.1.1 Input data TOC handles were used as the keywords (twitter handle of the TOCs), The start and end dates (1 September 2016 and 31 August 2017 ) are defined as input.

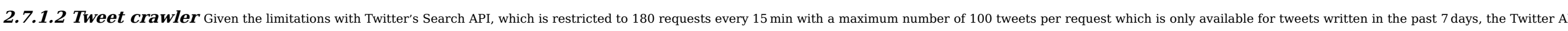

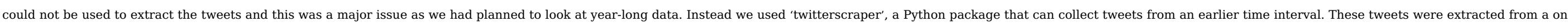
year period between 1 September 2016 and 31 August 2017, and contained the username of a TOC.

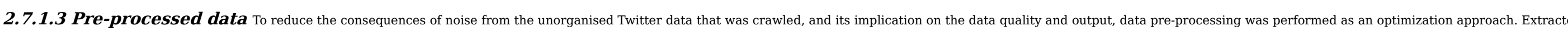

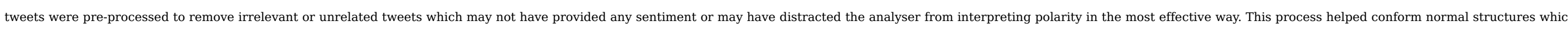

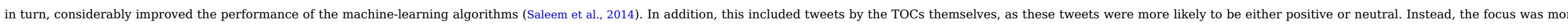
on the travellers' experiences and their tweets about the service.

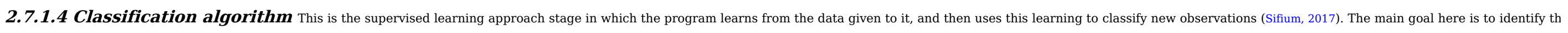
category/class under which new data will fall by using the naive Bayes algorithm classifier. Publicly available tweets involving 27 UK TOCs were divided into three groups: London and South East, regional, and long distance.



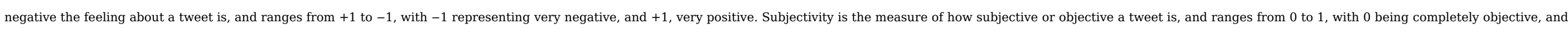
being completely subjective.

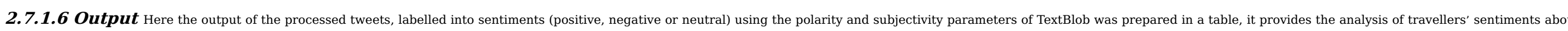
their experiences on the TOC. For the plots, we used the 'pandas-highcharts' Python package.

\subsubsection{Results}

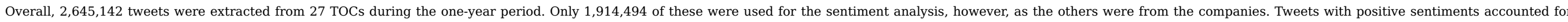

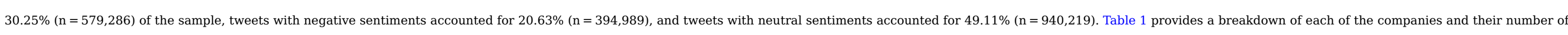


Table 1 Sentiment Analysis of all the Tweets across different Train Operating Companies.

\begin{tabular}{|c|c|c|c|c|c|c|c|c|c|c|c|c|c|}
\hline Tain Group & Train Compnay & Username & $\begin{array}{l}\text { Total } \\
\text { tweets }\end{array}$ & $\begin{array}{l}\text { accepted } \\
\text { tweets }\end{array}$ & $\begin{array}{l}\text { rejected } \\
\text { tweets }\end{array}$ & $\begin{array}{l}\text { Positive } \\
\text { tweets }\end{array}$ & $\begin{array}{c}\% \\
\text { Postive }\end{array}$ & $\begin{array}{l}\text { Negative } \\
\text { Tweets }\end{array}$ & $\begin{array}{c}\% \\
\text { Negative }\end{array}$ & $\begin{array}{l}\text { Neutral } \\
\text { Tweets }\end{array}$ & $\begin{array}{c}\% \\
\text { Neutral }\end{array}$ & $\begin{array}{l}\text { Diff (Postive- } \\
\text { Negative) }\end{array}$ & Average \\
\hline \multirow{16}{*}{$\begin{array}{l}\text { London and South } \\
\text { East }\end{array}$} & Abellio Greater Anglia & greateranglia & 216,999 & 171,097 & 45,902 & 49,496 & $29 \%$ & 34,746 & $20 \%$ & 86,855 & $51 \%$ & $9 \%$ & \\
\hline & $\mathrm{c} 2 \mathrm{c}$ & c2c_Rail & 102,917 & 69,642 & 33,275 & 18,013 & $26 \%$ & 13,919 & $20 \%$ & 37,710 & $54 \%$ & $6 \%$ & \\
\hline & Chiltern Railways & chilternrailway & 41,224 & 29,058 & 12,166 & 9678 & $33 \%$ & 6604 & $23 \%$ & 12,776 & $44 \%$ & $11 \%$ & \\
\hline & Gatwick Express & GatwickExpress & 23,074 & 15,930 & 7144 & 4196 & $26 \%$ & 2998 & $19 \%$ & 8736 & $55 \%$ & $8 \%$ & \\
\hline & Great Northern & GNRailUK & 96,923 & 68,093 & 28,830 & 17,589 & $26 \%$ & 16,249 & $24 \%$ & 34,255 & $50 \%$ & $2 \%$ & \\
\hline & Great Western Railway & GWRHelp & 184,623 & 144,110 & 40,513 & 42,239 & $29 \%$ & 38,097 & $26 \%$ & 63,774 & $44 \%$ & $3 \%$ & \\
\hline & Heathrow Connect* & HeathrowConnect & 160 & 160 & 0 & 24 & $15 \%$ & 70 & $44 \%$ & 66 & $41 \%$ & $-29 \%$ & \\
\hline & Heathrow Express & HeathrowExpress & 9116 & 6572 & 2544 & 2542 & $39 \%$ & 1134 & $17 \%$ & 2896 & $44 \%$ & $21 \%$ & \\
\hline & London Midland ${ }^{* *}$ & LondonMidland & 72,713 & 37,844 & 34,869 & 12,751 & $34 \%$ & 6203 & $16 \%$ & 18,890 & $50 \%$ & $17 \%$ & \\
\hline & London Overground & LDNOverground & 19,031 & 11,533 & 7498 & 3453 & $30 \%$ & 2462 & $21 \%$ & 5618 & $49 \%$ & $9 \%$ & \\
\hline & South West Trains & SW_Help & 78,850 & 74,414 & 4436 & 21,103 & $28 \%$ & 15,457 & $21 \%$ & 37,854 & $51 \%$ & $8 \%$ & \\
\hline & Southeastern & Se_Railway & 230,849 & 160,017 & 70,832 & 42,364 & $26 \%$ & 38,033 & $24 \%$ & 79,620 & $50 \%$ & $3 \%$ & \\
\hline & TfL Rail & TfLRail & 20,608 & 13,832 & 6776 & 3526 & $25 \%$ & 4347 & $31 \%$ & 5959 & $43 \%$ & $-6 \%$ & \\
\hline & Thameslink & TLRailUK & 130,717 & 86,661 & 44,056 & 21,628 & $25 \%$ & 20,934 & $24 \%$ & 44,099 & $51 \%$ & $1 \%$ & \\
\hline & Southern & SouthernRailUK & 327,160 & 205,496 & 121,664 & 50,254 & $24 \%$ & 46,709 & $23 \%$ & 108,533 & $53 \%$ & $2 \%$ & \\
\hline & Stansted Express & Stansted_Exp & 26,102 & 23,840 & 2262 & 13,311 & $56 \%$ & 2750 & $12 \%$ & 7779 & $33 \%$ & $44 \%$ & $7 \%$ \\
\hline \multirow[t]{4}{*}{ Regional } & Arriva Trains Wales & ArrivaTW & 90,988 & 66,559 & 24,429 & 23,887 & $36 \%$ & 12,595 & $19 \%$ & 30,077 & $45 \%$ & $17 \%$ & \\
\hline & Merseyrail & merseyrail & 46,117 & 35,691 & 10,426 & 12,290 & $34 \%$ & 7098 & $20 \%$ & 16,303 & $46 \%$ & $15 \%$ & \\
\hline & Northern Rail & northernassist & 152,714 & 122,527 & 30,187 & 35,629 & $29 \%$ & 28,090 & $23 \%$ & 58,808 & $48 \%$ & $6 \%$ & \\
\hline & ScotRail & ScotRail & 144,578 & 100,082 & 44,496 & 29,439 & $29 \%$ & 20,993 & $21 \%$ & 49,650 & $50 \%$ & $8 \%$ & $12 \%$ \\
\hline \multirow[t]{7}{*}{ Long-Distnace } & CrossCountry & CrossCountryUK & 94,144 & 72,674 & 21,470 & 25,133 & $35 \%$ & 12,243 & $17 \%$ & 35,298 & $49 \%$ & $18 \%$ & \\
\hline & East Midlands Trains & EMTrains & 96,809 & 72,312 & 24,497 & 25,224 & $35 \%$ & 12,297 & $17 \%$ & 34,791 & $48 \%$ & $18 \%$ & \\
\hline & First Hull Trains & Hull_Trains & 9119 & 6842 & 2277 & 2295 & $34 \%$ & 1563 & $23 \%$ & 2984 & $44 \%$ & $11 \%$ & \\
\hline & $\begin{array}{l}\text { First TransPennine } \\
\text { Express }\end{array}$ & TPExpressTrains & 14,438 & 4273 & 10,165 & 1608 & $38 \%$ & 686 & $16 \%$ & 1979 & $46 \%$ & $22 \%$ & \\
\hline & Grand Central & GC_Rail & 14,891 & 11,650 & 3241 & 4499 & $39 \%$ & 1694 & $15 \%$ & 5457 & $47 \%$ & $24 \%$ & \\
\hline & Virgin Trains & VirginTrains & 231,200 & 179,909 & 51,291 & 44,096 & $25 \%$ & 19,681 & $11 \%$ & 59,899 & $33 \%$ & $14 \%$ & \\
\hline & $\begin{array}{l}\text { Virgin Trains East } \\
\text { Coast }^{* * * *}\end{array}$ & Virgin_TrainsEC & 169,078 & 123,676 & 45,402 & 63,019 & $51 \%$ & 27,337 & $22 \%$ & 89,553 & $72 \%$ & $29 \%$ & $19 \%$ \\
\hline
\end{tabular}




\begin{tabular}{|l|l|l|l|l|l|l|l|l|l|l|l|l|}
\hline Total & $2,645,142$ & $1,914,494$ & 730,648 & 579,286 & $30 \%$ & 394,989 & $21 \%$ & 940,219 & $49 \%$ & $10 \%$ &
\end{tabular}

*Heathrow Connect services has been replaced with TfL Rail @TflRail (May 2018).

** London Midlands' franchise was replaced with London Northwestern Railway @LNRailway and West Midlands Railway @WestMidRailway (December 2017).

*** Virgin Trains East Coast has been replaced with London North Eastern Railway @LNER (June 2018).

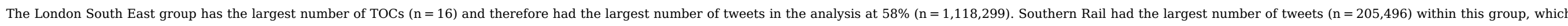

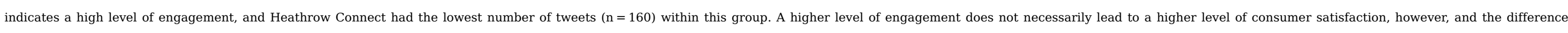

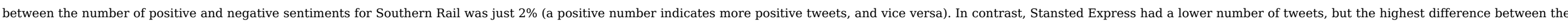
number of positive and negative tweets (44\%).



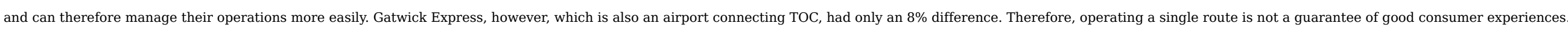

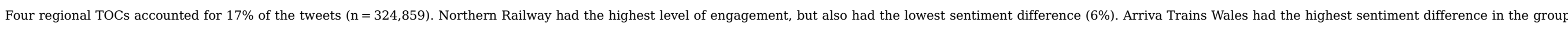
(17\%).

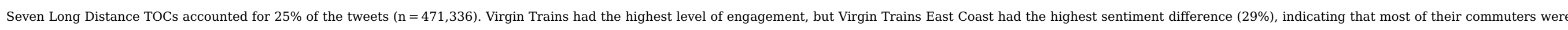
happy with their experience. Overall, the Long Distance TOCs are seen in a positive light, with average sentiment difference of $19 \%$ compared to London's $7 \%$.

\section{Study 2}

\subsection{Study 2 thematic analysis}

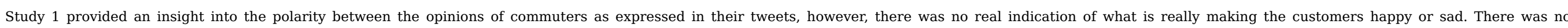

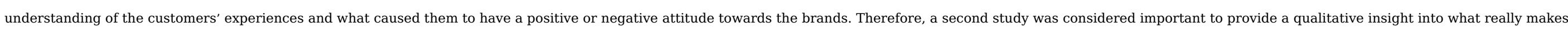

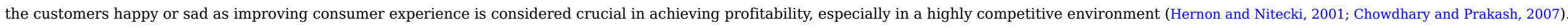

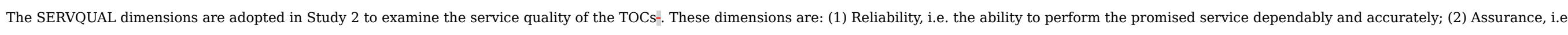

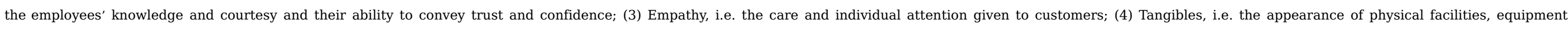

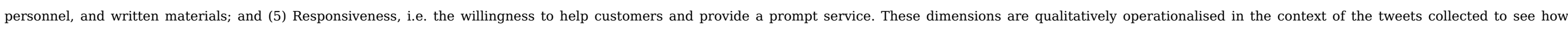
consumers describe the quality of the service they receive.

\subsubsection{Methodology}

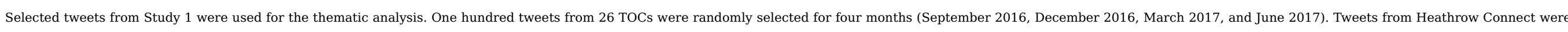
excluded as there were only 160 tweets throughout the 12 -month period. In total, 2־ְ̋00 tweets from each month (10,400 in total) were saved as PDFs and imported into NVivo10, a qualitative thematic analysis tool.

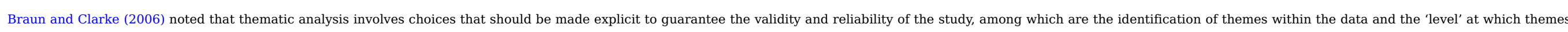

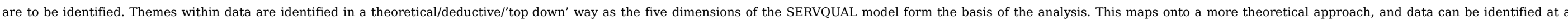
semantic level as the themes are identified within the explicit or surface meanings of the tweets.

The six phases of analysis outlined by Braun and Clarke (2006) were adopted for the data analysis.

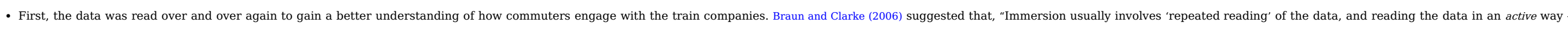
searching for meanings, patterns and so on". 
- Second, the initial codes were generated. As the themes were more 'theory-driven', the coding was approached with the SERVQUAL features in mind. The SERVQUAL dimensions were considered as parent nodes in NVIVO during the analysis.

- Third, a search for themes (child nodes) related to the main themes (parent nodes) was conducted, e.g. identifying Wi-Fi and toilet facilities as Tangibles, and cancellations and train delays as Reliability.

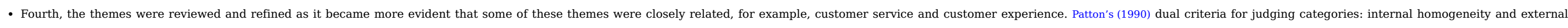
heterogeneity, were also considered as suggested.

- Fifth, the refined child nodes were considered satisfactory and renamed to fit into the five SERVQUAL dimensions.

- Finally, the report is presented in the next section to demonstrate how consumers express their concerns with regards to the perceived service quality.

\subsubsection{Results}

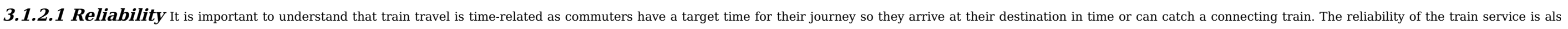

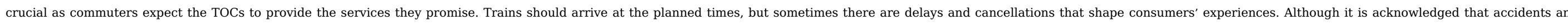

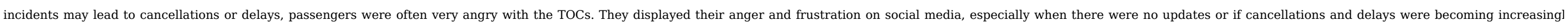

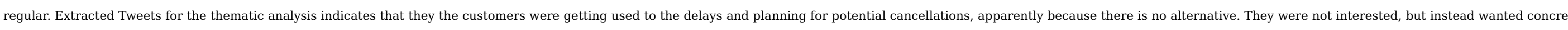
action to be taken to improve the quality of the service.

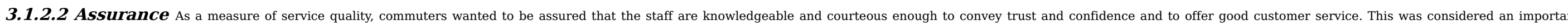

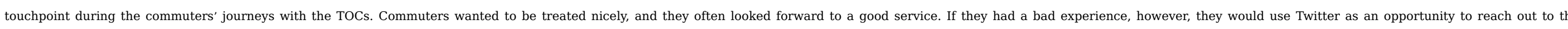
operators. There were issues with train drivers' strikes or services being cancelled due to driver unavailability. These issues added to the frustration of the commuters.

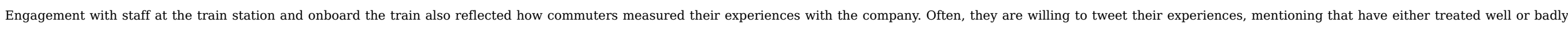

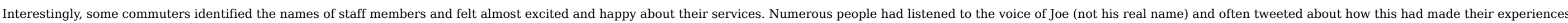
enjoyable.


commuters felt they deserved more than this and wanted the companies to improve their services.

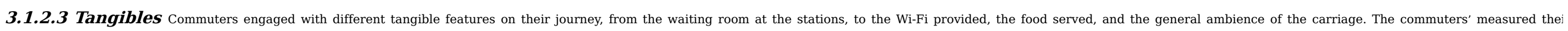

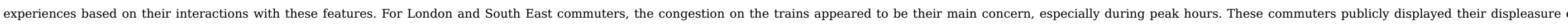

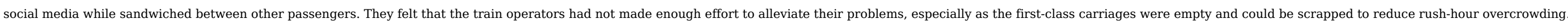

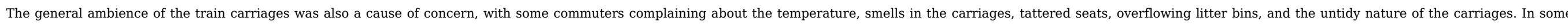
situations, commuters often complained to and mentioned government officials, such as their MP, to see if they could do something to ease the problem.

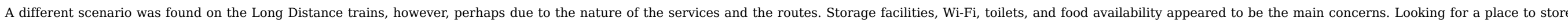

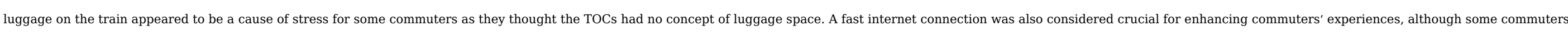

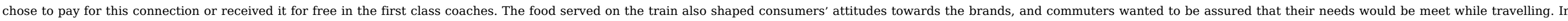
addition to other Tangibles, the state of the available toilets within the carriages was also found to shape attitudes towards the TOCs.

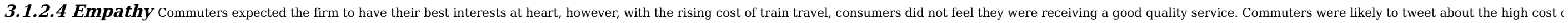

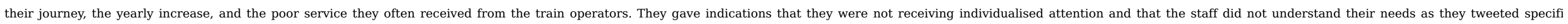
questions about travel, the best ticket to buy, and cancellations on their route.

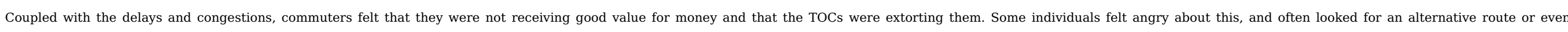

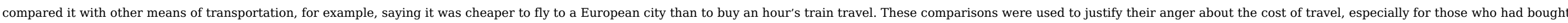




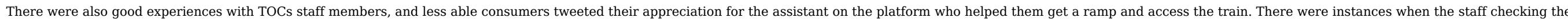

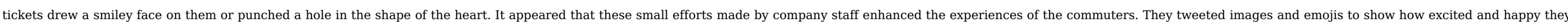
were.

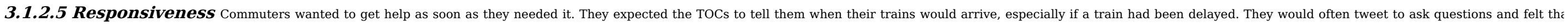
there should be someone on Twitter who was able to answer their queries. They also felt that the TOCs should be reachable and responsive, especially during rush hour.

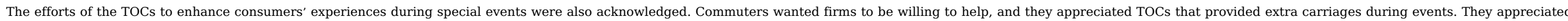
the gestures of the TOCs that would lead to a more positive attitude towards the brand. Likewise, TOCs that did not plan for such events were considered uncaring

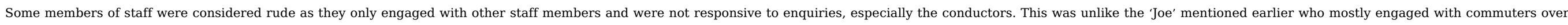

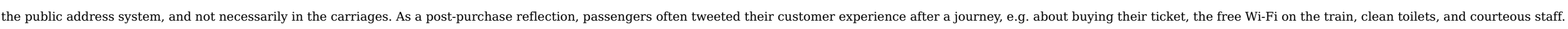

\section{Content analysis}

\subsection{Study 3}

\subsubsection{Study 3 content analysis}

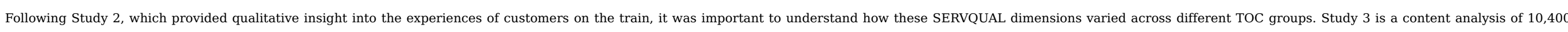
tweets from Study 2, performed to quantitatively understand how the service quality measures vary across the different train groups.

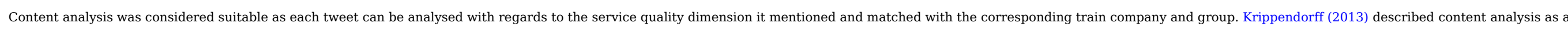

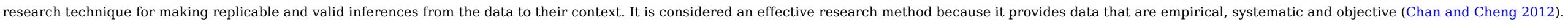

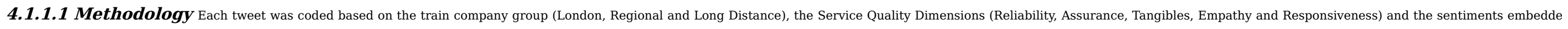
in the tweets (positive, negative or neutral). Coders were expected to read the tweets and code if the tweet describes any or all of the service quality measures and if these descriptions were positive, negative or neutral.

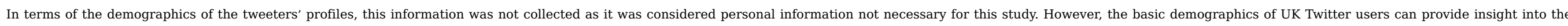

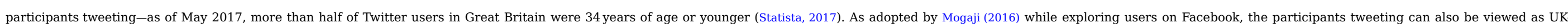
based residents who regularly use the trains as non-residents are not expected to regularly tweet about their daily commute on UK TOCs.

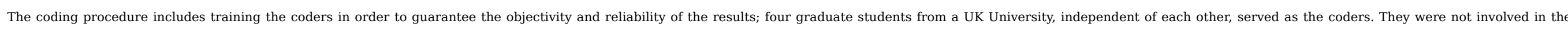

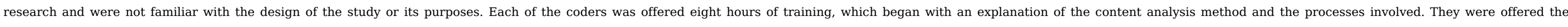

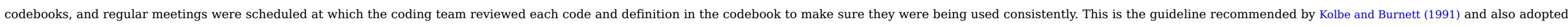
by Mogaji (2016). They coded all the tweets for this study and the process lasted for 2 weeks.

As Krippendorff (2013) noted, valid coding relies greatly on data and instrument reliability. The following steps were adopted from Mogaji (2016) to test intercoder reliability:

(1) 100 tweets from 26 train operating companies (randomly chosen from 2600 tweets posted between October and January 2017) were selected to test intercoder reliability between the four coders.

(2) The different categories of analysis were pre-tested, and each coder coded the tweets.

(3) The findings were compared.

(4) An intercoder reliability check was assessed using both Cohen's Kappa and Krippendorff's alpha level of agreement. These ranged from 0.993 to 1.00, which is consistent with Neuendorf's (2002) 'rules of thumb'. 


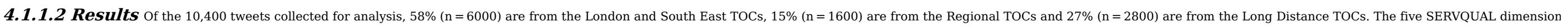
and embedded sentiments were also considered in the tweets regarding each of the three groups. Table 2 presents the content analysis of the tweets across various sentiments and train groups.

Table 2 Content Analysis of Tweets.

\begin{tabular}{|c|c|c|c|c|c|c|c|c|}
\hline \multirow[t]{3}{*}{ SERVQUAL Dimensions } & \multirow{2}{*}{\multicolumn{2}{|c|}{ London $\mathrm{N}=6000$}} & \multicolumn{2}{|c|}{ Sentiments } & & & & \\
\hline & & & \multicolumn{2}{|c|}{ Positive } & \multicolumn{2}{|c|}{ Negative } & \multicolumn{2}{|c|}{ Neutral } \\
\hline & $\mathrm{n}$ & $\%$ & & & & & & \\
\hline Reliability & 2651 & 44.18 & 708 & $27 \%$ & 1425 & $54 \%$ & 518 & $20 \%$ \\
\hline Assurance & 506 & 8.43 & 202 & $40 \%$ & 275 & $54 \%$ & 29 & $6 \%$ \\
\hline Tangibles & 1692 & 28.21 & 513 & $30 \%$ & 891 & $53 \%$ & 288 & $17 \%$ \\
\hline Empathy & 302 & 5.03 & 73 & $24 \%$ & 74 & $25 \%$ & 155 & $51 \%$ \\
\hline Responsiveness & 849 & 14.15 & 301 & $35 \%$ & 415 & $49 \%$ & 133 & $16 \%$ \\
\hline & \multirow{2}{*}{\multicolumn{2}{|c|}{ Regional $\mathrm{N}=1600$}} & \multicolumn{2}{|c|}{ Sentiments } & & & & \\
\hline & & & \multicolumn{2}{|c|}{ Positive } & \multicolumn{2}{|c|}{ Negative } & \multicolumn{2}{|c|}{ Neutral } \\
\hline Reliability & 94 & 5.87 & 42 & $45 \%$ & 40 & $43 \%$ & 12 & $13 \%$ \\
\hline Assurance & 215 & 13.44 & 97 & $45 \%$ & 88 & $41 \%$ & 30 & $14 \%$ \\
\hline Tangibles & 410 & 25.63 & 104 & $25 \%$ & 279 & $68 \%$ & 27 & $7 \%$ \\
\hline Empathy & 677 & 42.31 & 470 & $69 \%$ & 68 & $10 \%$ & 139 & $21 \%$ \\
\hline \multirow[t]{3}{*}{ Responsiveness } & 204 & 12.75 & 109 & $53 \%$ & 61 & $30 \%$ & 34 & $17 \%$ \\
\hline & \multirow{2}{*}{\multicolumn{2}{|c|}{ Long Distance $\mathrm{N}=2800$}} & \multicolumn{2}{|c|}{ Sentiments } & & & & \\
\hline & & & \multicolumn{2}{|c|}{ Positive } & \multicolumn{2}{|c|}{ Negative } & \multicolumn{2}{|c|}{ Neutral } \\
\hline Reliability & 309 & 11.03 & 213 & $69 \%$ & 81 & $26 \%$ & 15 & $5 \%$ \\
\hline Assurance & 789 & 28.18 & 455 & $58 \%$ & 231 & $29 \%$ & 103 & $13 \%$ \\
\hline Tangibles & 1007 & 35.97 & 725 & $72 \%$ & 196 & $19 \%$ & 86 & $9 \%$ \\
\hline Empathy & 512 & 18.28 & 247 & $48 \%$ & 119 & $23 \%$ & 146 & $29 \%$ \\
\hline Responsiveness & 183 & 6.54 & 94 & $51 \%$ & 40 & $22 \%$ & 49 & $27 \%$ \\
\hline
\end{tabular}

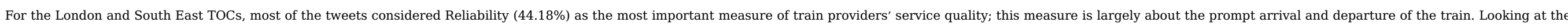

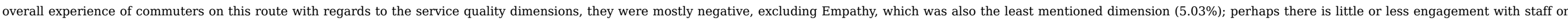

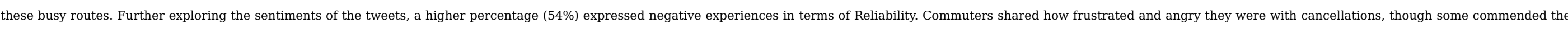
TOC for timely arrival (27\%)-perhaps as a way of showing how surprised they were with the prompt service.

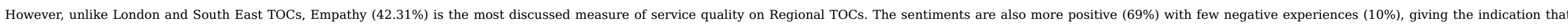

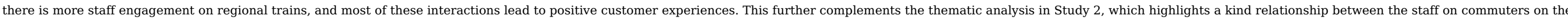

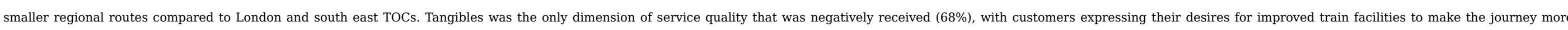




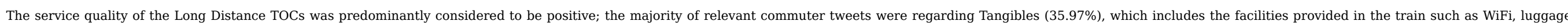

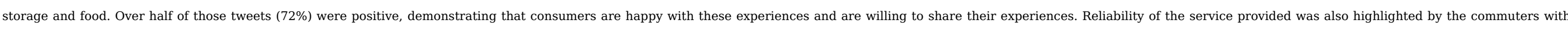
more positive tweets (69\%). However, Responsiveness (6.54\%) was the lowest measure of service quality.

\section{Discussion}

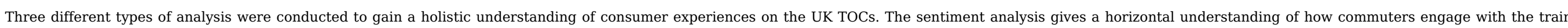

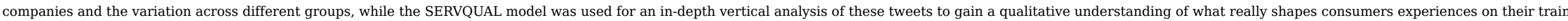
journeys. Finally, the content analysis provided a quantitative insight for a better understanding of the service quality variations across the different TOC groups.

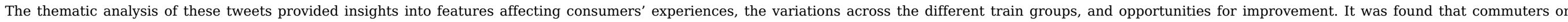

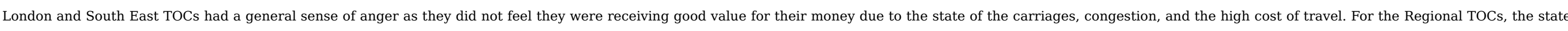
of the carriages was a significant concern, while the Long Distance TOCs also needed to improve Tangibles such as storage facilities and internet facilities.

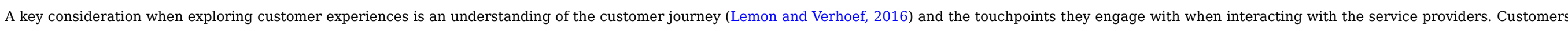

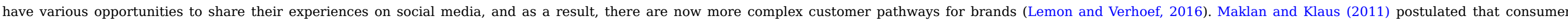

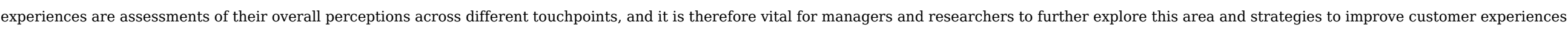

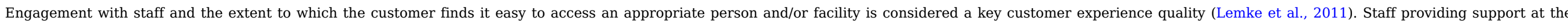

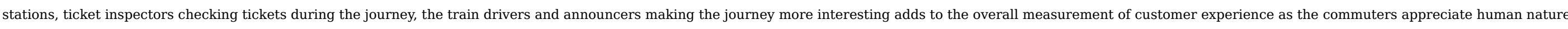
and a welcoming atmosphere while onboard the train.

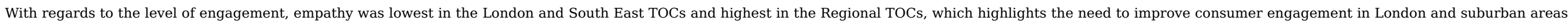
The busy nature of these routes could be the reason for these differences, and this offers an opportunity to consider and see how London and South East TOC staff can engage with commuters.

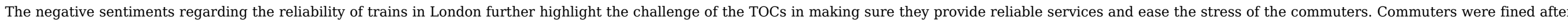
being forced to stand in first-class carriages due to overcrowding, leading to the call to scrap first-class carriages on busy suburban routes in a bid to reduce rush hour overcrowding (Gregory, 2017).

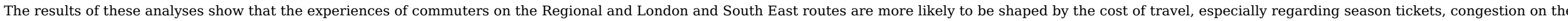

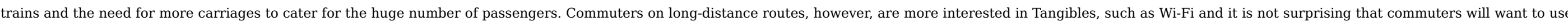

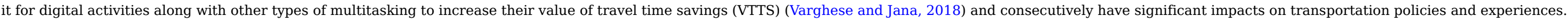

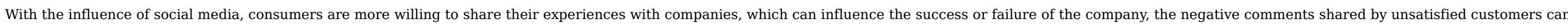

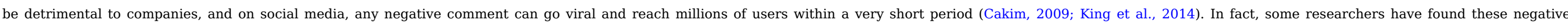
conversations to more influential than the positive ones (Chevalier and Mayzlin, 2006; Mittal et al., 1998).

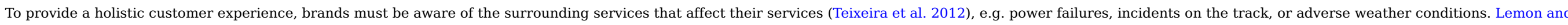

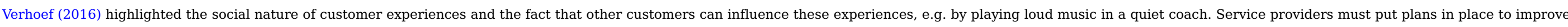
their service failure and to reassure customers of the quality of services.

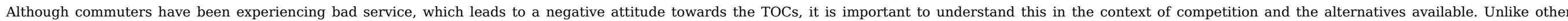

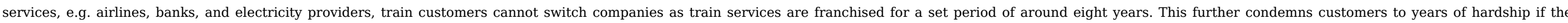

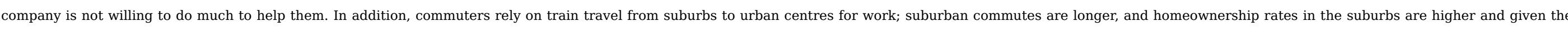

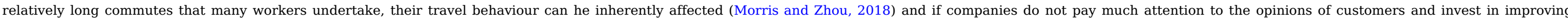




\section{Conclusion}

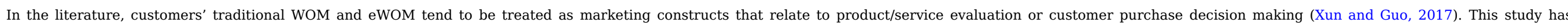

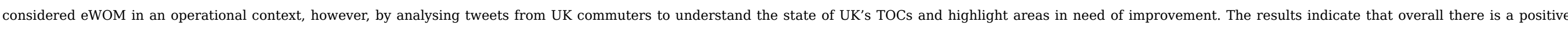


the train transportation industry in UK.

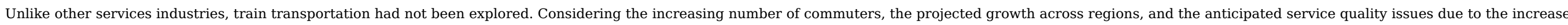
in demand, this research offers a theoretical contribution towards the existing knowledge of consumer experiences and attitudes.

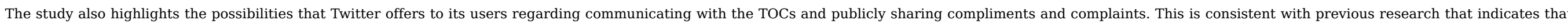

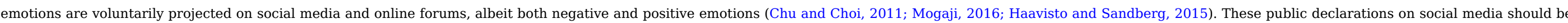

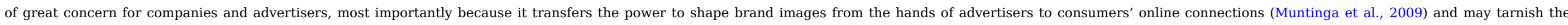
reputation of the TOCs (Schweitzer, 2014).



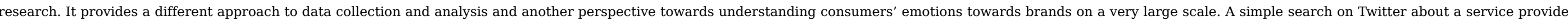

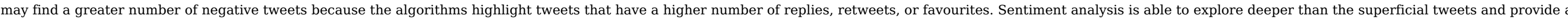

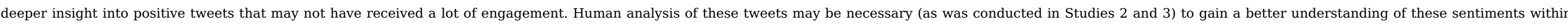
their context.

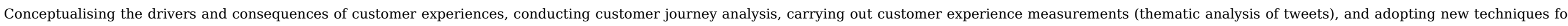

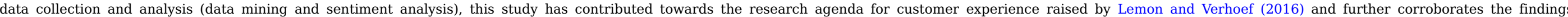

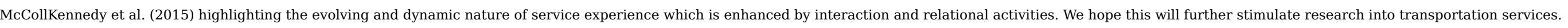

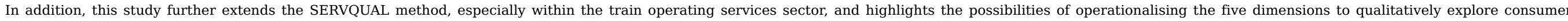
experiences with UK's TOCs. Quantitative measures are often adopted in SERVQUAL, but this study explored the verbal feedback of commuters as qualitative data.

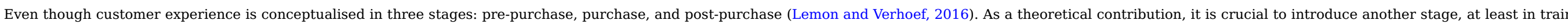

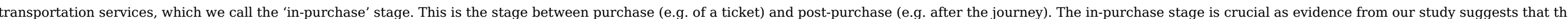
experiences of the commuters during their journey are crucial and are not covered by this existing typology.

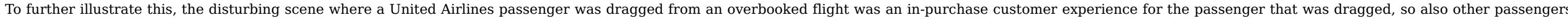

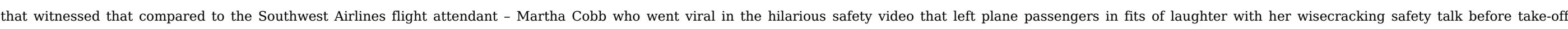

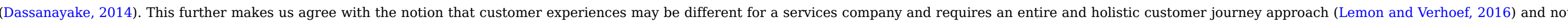
just at the three distinct touch points.

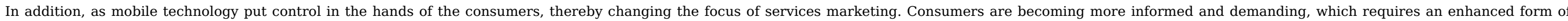


creation experience dimensions of the service (Ostrom et al., 2015; Verleye, 2015).

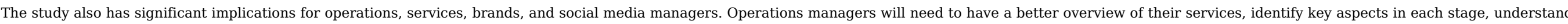




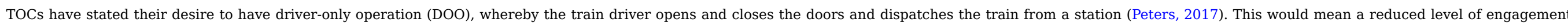

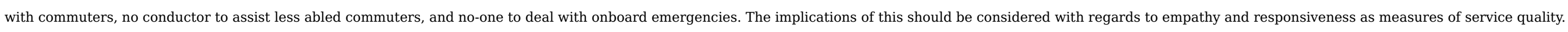

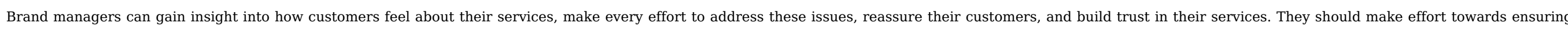

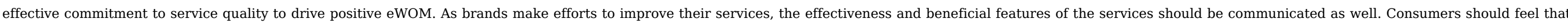
the brands are more efficient, emphatic, and ready to solve their problems.

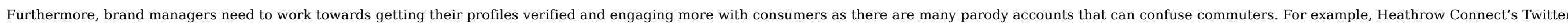

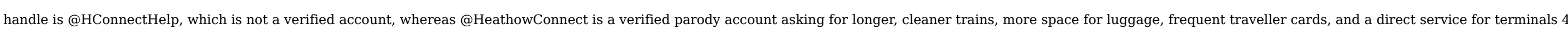
and 5. Often, these parody accounts share negative experiences about the brand, which is another reason for brands to take charge of their communication strategies.

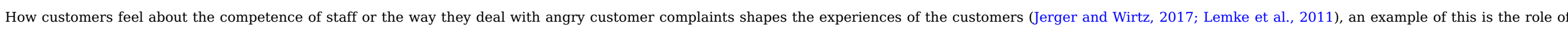

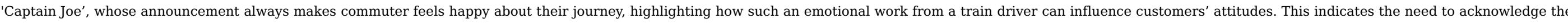

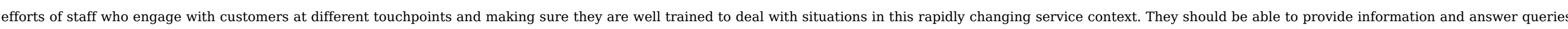
while treating customers with courtesy.

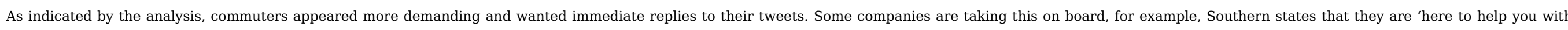



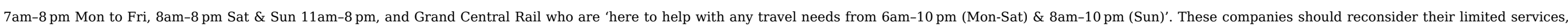
however, especially as responsiveness and empathy are measures of service quality.

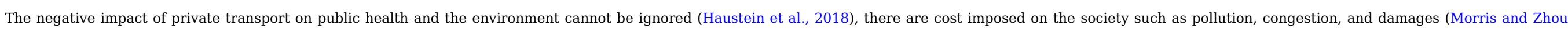

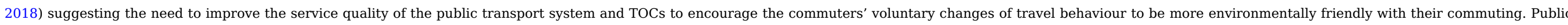

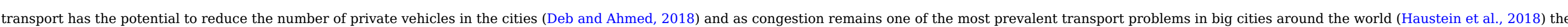

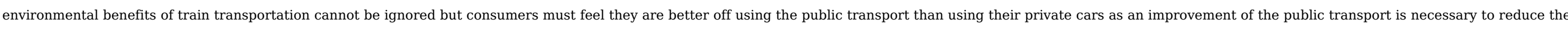
dependency on the private cars (Deb and Ahmed, 2018).

\section{Limitations}

The fact that this study is based on real-life responses from social media network users can be considered one of its main strengths, but several limitations still need to be addressed

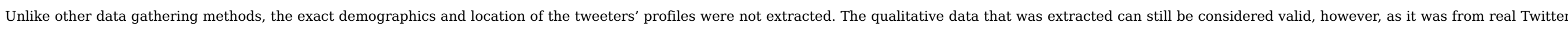

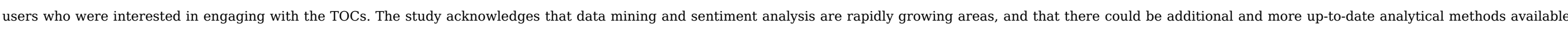
that could perform a better analysis, however, we are confident of the rigour of this study.

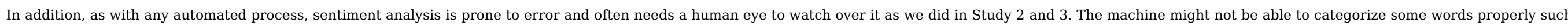

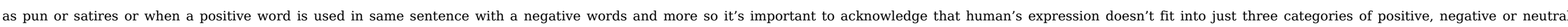
sentiments but as Bannister (2015) noted, the insight that can be gained from large datasets (millions of Tweets) will overshadow the concerns about reliability at a granular level (a single Tweet).



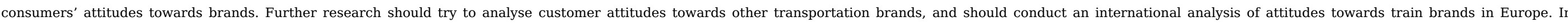

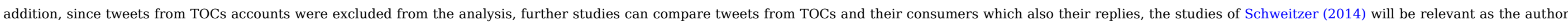
explored tweets from the companies. 


\section{Uncited references}

Dixon et al. (2010), Reichheld (2003).

\section{Acknowledgment}

The authors would like to thank Jason Pallant and the anonymous reviewers for their thoughtful comments on the manuscript.

\section{Appendix A. Supplementary data}

Supplementary data to this article can be found online at https://doi.org/10.1016/j.tbs.2018.09.004.

\section{References}

Bannister, K., 2015. Understanding Sentiment Analysis: What It Is \& Why It’s Used. https://www.brandwatch.com/blog/understanding-sentiment-analysis/ (Accessed 66 2018).


Barreda A.A., Bilgihan A., Nusair K. and Okumus F., Generating brand awareness in online social networks, Comput. Hum. Behav. 50 (September), $2015,600-609$. Brady M.K. and Cronin Joseph J., Jr., Some new thoughts on conceptualizing perceived service quality: a hierarchical approach, J. Market. 65 (3), 2001 , 34-49.

Brakus J.J., Schmitt B.H. and Zarantonello L., Brand experience: what is it? How is it measured? Does it affect loyalty?, J. Market. 73 (3), $2009,52-68$.

Braun V. and Clarke V., Using thematic analysis in psychology, Qual. Res. Psychol. 3 (2), 2006, 77-101.

Cakim I.M., Implementing word of mouth marketing: online strategies to identify influencers, craft stories, and draw customers, 2009, John Wiley \& Sons; Hoboken, NJ.

Canhoto A.I. and Clark M., Customer service 140 characters at a time: the users' perspective, J. Market. Manage. 29 (5-6), 2013, 522-544.

Casteleyn J., Mottart A. and Rutten K., How to use data from Facebook in your market research, Int. J. Market Res. 51 (4), 2009, 439-447.

Chan K. and Cheng Y., Portrayal of females in magazine advertisements in Hong Kong, J. Asian Pacific Commun. 22 (1), 2012, 78-96.

Chevalier J.A. and Mayzlin D., The effect of word of mouth on sales: online book reviews, J. Market. Res. 43 (3), 2006, 345-354.

Chowdhary N. and Prakash M., Prioritizing service quality dimensions, Managing Serv. Qual. 17 (5), 2007, 493-509.

Chu S.C., Chen H.T. and Sung Y., Following brands on Twitter: an extension of theory of planned behavior, Int. J. Advertising 35 (3), $2016,421437$.

Chu S. and Choi S.M., Electronic word-of-mouth in social networking sites: a cross-cultural study of the United States and China, J. Global Market. 24 (3), 2011, 263-281.

Cox, J., 2014. Why Are UK Rail Fares So Expensive? http://www.independent.co.uk/travel/uk/why-are-uk-rail-fares-so-expensive9678640.html (Accessed 3 3, 2018).


Cobb-goes-viral-in-hilarious-safety-video (Accessed 3 3, 2018).

Davis S.M. and Dunn M., Building the Brand-Driven Business: Operationalize Your Brand to Drive Profitable Growth, 2002, Jossey-Bass; San Francisco, CA.

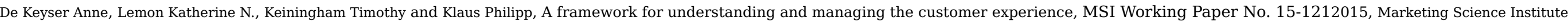
Cambridge, MA.

Deb S. and Ahmed M.A., Determining the service quality of the city bus service based on users' perceptions and expectations, Travel Behav. Soc. 12, $2018,1-10$.

Dixon M., Freeman K. and Toman N., Stop trying to delight your customers, Harvard Bus. Rev. 88 (7/8), 2010, 116-122. 
Erkan I. and Evans C., The influence of eWOM in social media on consumers' purchase intentions: an extended approach to information adoption, Comput. Hum. Behav. 61 (August), $2016,47-55$.

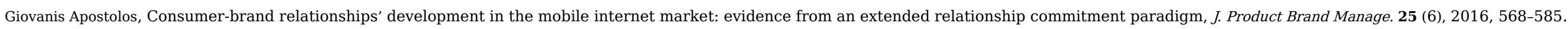

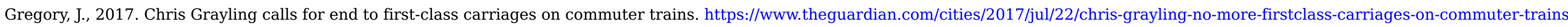

(Accessed 3 3, 2018).

Haavisto P. and Sandberg B., "Man, this frustrates me": change of consumer emotions in online discussions, J. Res. Interact. Marketing $\mathbf{9}$ (1), $2015,70-87$.

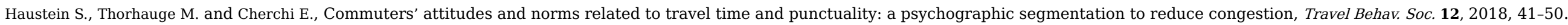

He, S.Y., Miller, E.J., Scott, D.M., 2018. “Big data and travel behaviour.” (2017). 11 (April), 119-120.

Heller Baird C. and Parasnis G., From social media to social customer relationship management, Strat. Leadership 39 (5), $2011,30-37$.

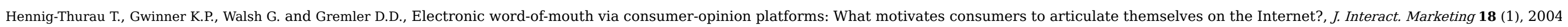
$38-52$.

Hernon P. and Nitecki D.A., Service quality: a concept not fully explored, Library Trends 49 (4), 2001, 687-708.

Homburg C., Jozić D. and Kuehnl C., Customer experience management: toward implementing an evolving marketing concept, J. Acad. Market. Sci. 45 (3), 2017 , 377-401.

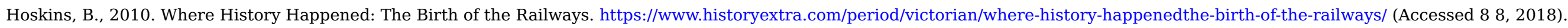

Internet Live Stats, 2018. Twitter Usage Statistics. http://www.internetlivestats.com/twitter-statistics (Accessed 3 3, 2018).

Izogo Ernest Emeka, Customer loyalty in telecom service sector: the role of service quality and customer commitment, TQM J. 29 (1), $2017,19-36$.

Jerger C. and Wirtz J., Service employee responses to angry customer complaints: the roles of customer status and service climate, J. Serv. Res. 20 (4), 2017, 362-378.

Kim E., Sung Y. and Kang H., Brand followers' retweeting behavior on Twitter: how brand relationships influence brand electronic word-of-mouth, Comput. Hum. Behav. 37 (August), 2014 , $18-25$.

King R.A., Racherla P. and Bush V.D., What we know and don't know about online word-of-mouth: a review and synthesis of the literature, J. Interact. Marketing 28 (3), 2014 , 167-183.

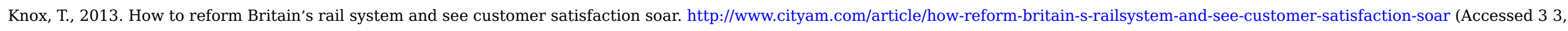
2018).

Kolbe R.H. and Burnett M.S., Content-analysis research: an examination of applications with directives for improving research reliability and objectivity, J. Consumer Res. 18 (2), 1991, $243-250$.

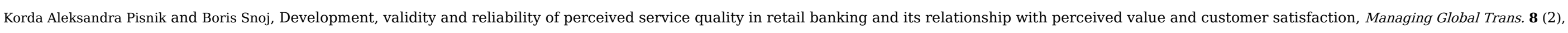
2010, 187-205.

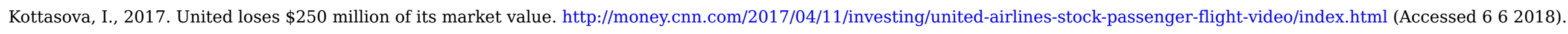

Kozinets R.V., De Valck K., Wojnicki A.C. and Wilner S.J., Networked narratives: understanding word-of-mouth marketing in online communities, J. Marketing 74 (2), 2010 , 71-89.

Krippendorff K., Content analysis: an introduction to its methodology, 3rd., 2013, Sage; Thousand Oaks, CA.

Kunz W., Aksoy L., Bart Y., Heinonen K., Kabadayi S., Ordenes F.V. and Theodoulidis B., Customer engagement in a big data world, J. Serv. Mark. 31 (2), 2017 , 161-171.

Lemke F., Clark M. and Wilson H., Customer experience quality: an exploration in business and consumer contexts using repertory grid technique, J. Acad. Mark. Sci. 39 (6), 2011, 846-869.

Lemon Katherine N and Verhoef Peter C, Understanding customer experience throughout the customer journey, J. Marketing 80 (6), 2016, 69-96. 


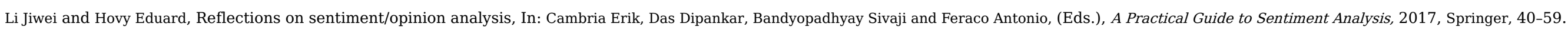

Loo B.P., Chen C. and Chan E.T., Rail-based transit-oriented development: lessons from New York City and Hong Kong, Landsc. Urban Plann. 97 (3), $2010,202-212$.


Limited; London, UK, 149-168.

Maklan S. and Klaus P., Customer experience: are we measuring the right things, Int. J. Market Res. 53 (6), 2011, 771-792.

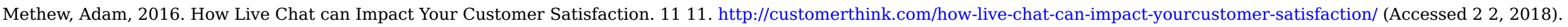

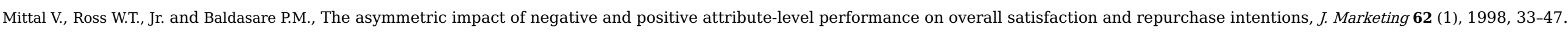

Moeller Sabine, Characteristics of services - a new approach uncovers their value, J. Serv. Mark. 24 (5), 2010, 359-368.

Mogaji E., This advert makes me cry: disclosure of emotional response to advertisement on Facebook, Cogent Bus. Manage. 3 (1), $2016,1-19$.

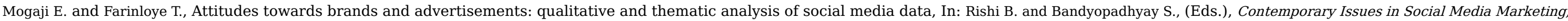
2017, Routledge; London, 206-216.



Moran G. and Muzellec L., eWOM credibility on social networking sites: a framework, J. Market. Commun. 23 (2), 2017, 149-161.

Morris E.A. and Zhou Y., Are long commutes short on benefits? Commute duration and various manifestations of well-being, Travel Behav. Soc. 11, 2018, 101-110.


2018).

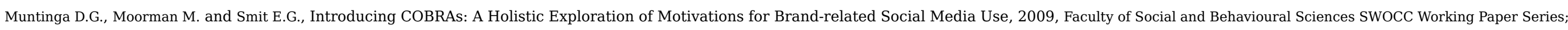
Amsterdam.

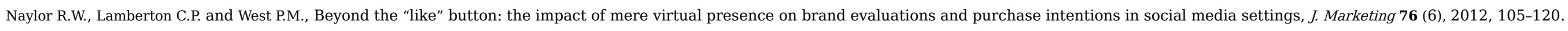

Neuendorf K.A., The Content Analysis Guidebook, 2002, Sage; Thousand Oaks, CA.

Ostrom Amy L., Parasuraman Ananthanarayanan, Bowen David E., Patricio Lia and Voss Christopher A., Service research priorities in a rapidly changing context, J. Serv. Res. 18 (2), 2015, 127-159.

Parasuraman A., Zeithaml Valarie A. and Berry Leonard, SERVQUAL: a multiple-item scale for measuring consumer perceptions of service quality, J. Retail. 64 (1), $1988,12-40$.

Patton M.Q., Qualitative Evaluation and Research Methods, 2nd ed., 1990, Sage; Newbury Park, CA.

Peluffo Nicholas, Rail Passenger Numbers and Crowding on Weekdays in Major Cities in England and Wales, 2017, Department for Transport; London.

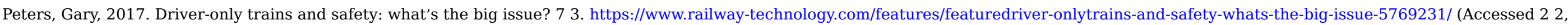
2018).

Ponsignon F., Durrieu F. and Bouzdine-Chameeva T., Customer experience design: a case study in the cultural sector, J. Serv. Manage. 28 (4), $2017,763-787$.

Raassens N. and Haans H., NPS and online WOM: investigating the relationship between customers' promoter scores and eWOM behavior, J. Serv. Res. 20 (3), 2017, 322-334.

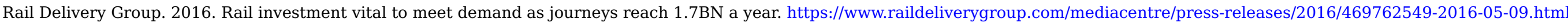


(Accessed 3 3, 2018).

Reichheld F.F., The one number you need to grow, Harvard Bus. Rev. 81 (6), 2003, 46-55.

Russell M.A., Mining the Social Web: Analyzing data from Facebook, Twitter, LinkedIn, and Other Social Media Sites, 2011, O’Reilly Media; Sebastopol, CA.

Sabrina Trudeau H. and Shobeiri Saeed, The relative impacts of experiential and transformational benefits on consumer-brand relationship, J. Product Brand Manage. 25 (6), 2016, 586-599.



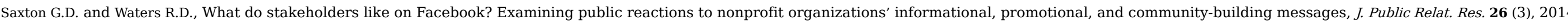
280-299.

Schweitzer L., Planning and social media: a case study of public transit and stigma on Twitter, J. Am. Plann. Assoc. 80 (3), 2014, 218-238.

Sifium, 2017. Types of classification algorithms in Machine Learning. https://medium.com/@sifium/machine-learning-types-of-classification-9497bd4f2e14 (Available 6 6, 2018).

Smith, O., 2016. Mapped: The world's largest rail networks. http://www.telegraph.co.uk/travel/maps-and-graphics/Mapped-The-worldslargest-rail-networks/ (Accessed 3 3, 2018).

Soleymania Mohammad, Garciab David, Jouc Brendan, Schullere Björn, Chang Shih-Fu and Pantic Maja, A survey of multimodal sentiment analysis, Image Vis. Comput. 65 (September), 2017 , 3-14.

Smith D., Beyond Rail: The Capacity Challenge, 2017, OnTrac; London.

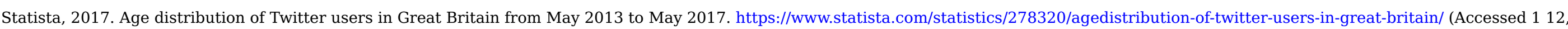
2018).

Swinyard W.R., The effects of mood, involvement, and quality of store experience on shopping intentions, J. Consumer Res. 20 (2), 1993, 271-280.

Tafesse W., Content strategies and audience response on Facebook brand pages, Marketing Intell. Plann. 33 (6), 2015, 927-943.

Teixeira J., Patrício L., Nunes N.J., Nóbrega L., Fisk R.P. and Constantine L., Customer experience modeling: from customer experience to service design, J. Serv. Manage. 23 (3), 2012, 362-376.

Toder-Alon A., Brunel F.F. and Fournier S., Word-of-mouth rhetorics in social media talk, J. Market. Commun. 20 (1-2), 2014, 42-64.

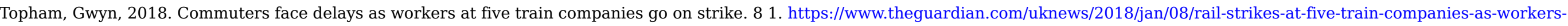

walkout\#img-1 (Accessed 2 2, 2018).

Trusov M.M., Bodapati A.V. and Bucklin R.E., Determining influential users in internet social networks, J. Mark. Res. 47 (4), $2010,643658$.

Varghese V. and Jana A., Impact of ICT on multitasking during travel and the value of travel time savings: empirical evidences from Mumbai, India, Travel Behav. Soc. 12, 2018, 11-22.

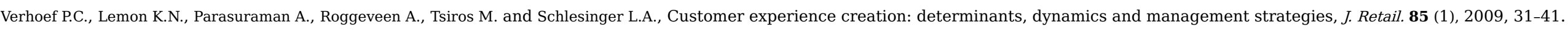

Verleye K., The co-creation experience from the customer perspective: its measurement and determinants, J. Serv. Manage. 26 (2), 2015, 321342.

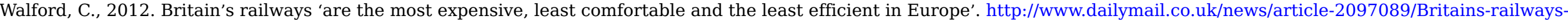

expensivecomfortable-efficient-Europe.html\#ixzz4 (Accessed 3 3, 2018).

Wang X., Yu C. and Wei Y., Social media peer communication and impacts on purchase intentions: a consumer socialization framework, J. Interact. Market. 26 (4), 2012 , 198-208.

Xun Jiyao and Guo Biao, Twitter as customer's eWOM: an empirical study on their impact on firm financial performance, Internet Res. 27 (5), $2017,10141038$.

\section{Appendix A. Supplementary data}




\section{Highlights}

- Three analyses of commuters' tweets to explore experience on train services.

- Tweet mining and sentiment analysis to investigate the polarity between the opinions.

- Thematic and Content Analysis of tweets to identify variations in service quality.

- There is an overall positive customer experiences on UK Train Transportation.

- Variations in service quality dimension across the different train groups.

\section{Queries and Answers}

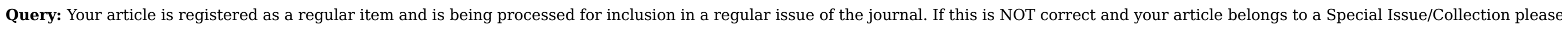
contact i.ravanan@elsevier.com immediately prior to returning your corrections.

Answer: Yes. It is a regular item for a regular issues

Query: The author names have been tagged as given names and surnames (surnames are highlighted in teal color). Please confirm if they have been identified correctly. Answer: Yes

Query: The country name has been inserted for the affiliations. Please check, and correct if necessary.


Greenwich

Query: Please check the edits made in the affiliation "b", and correct if necessary.

Answer: Yes.That's correct

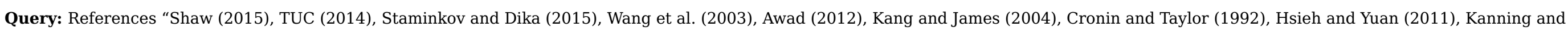

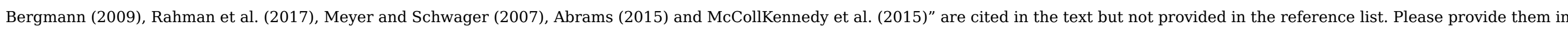
the reference list or delete these citations from the text.

Answer: Shaw (2015) - SHAW, M., 2015. Rail Passenger Numbers and Crowding On Weekdays In Major Cities In England And Wales. London: Rail Executive.

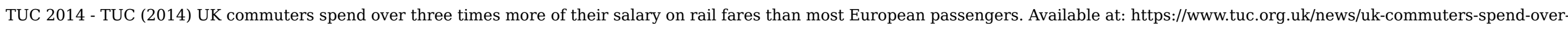
three-times-more-their-salary-rail-fares-most-european-passengers (Accessed: 9 Oct 2018).

Staminkov and Dika (2015) - Stamenkov, G. and Dika, Z. (2015), “A sustainable e-service quality model”, Journal of Service Theory and Practice, Vol. 25 No. 4, pp. 414-442.

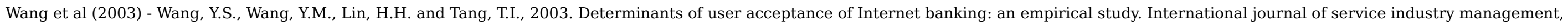
14(5), pp.501-519.

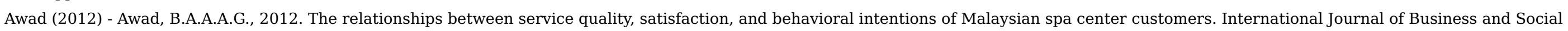


Science, 3(1). Pp. 198-205

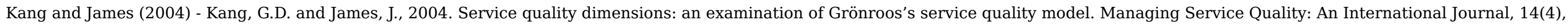
pp.266-277.

Cronin and Taylor (1992) - Cronin Jr, J.J. and Taylor, S.A., 1992. Measuring service quality: a reexamination and extension. The journal of marketing, 56(3), pp. 55-68pp.55-68.


Service Sciences, IJCSS 2011, 97-104. doi:10.1109/IJCSS.2011.27

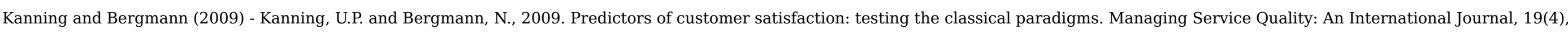
pp.377-390.

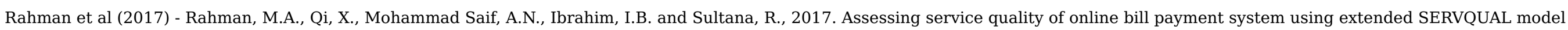
(SERVQUAL-Butterfly model): A case study of Dhaka electric supply company limited (DESCO), Bangladesh. Cogent Business \& Management, 4(1), p.1301195.

https://doi.org/10.1080/23311975.2017.1301195

Meyer and Schwager (2007) - Meyer, C. and Schwager, A., 2007. Customer experience. Harvard business review, 85(2), pp.116-126.

Abrams (2015) - ABRAMS, M., 2015. Passenger's Guide to Franchising. London, UK: Campaign for Better Transport.

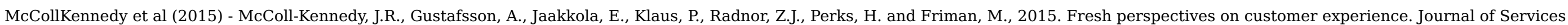
Marketing, 29(6/7), pp.430-435.

Query: Please check the hierarchy of the section headings.

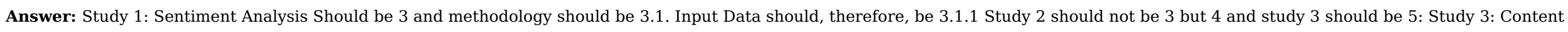
Analysis. No need for 4.1

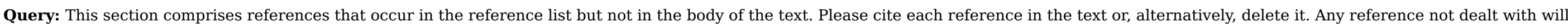
be retained in this section.

Answer: Please delete

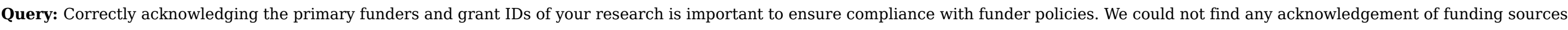
in your text. Is this correct? /

Answer: Yes 